essay will be expected to treat of the energy transformations of the circulation as a general theme or any particular aspects of that theme. It may be an essay in which the author describes and discusses the salient and essential features of the general circulation and the energy transformations involved; it may be an essay which attempts an adequate synopsis and discussion of the observations, or a study of the thermodynamics and hydrodynamics of the circulation ; or the essay may treat of any combination of these within the general theme. The essay, which must be in English, may include material which the candidate has already published. Essays may be submitted jointly in the names of more than one author. All entries must be addressed to the Assistant Secretary, Royal Meteorological Society, 49 Cromwell Road, London, S.W.7, and marked clearly 'Napier Shaw Prize', and should be received at the Society's Offices not later than March 4, 1956.

\section{Royal Society of Edinburgh : New Fellows}

THE following have been elected Fellows of the Royal Society of Edinburgh: Dr. H. M. Adam, senior lecturer in pharmacology, University of Edinburgh ; Mr. J. K. Allan, chief geologist, Netional Coal Board, London; Mr. B. L. Burtt, principal scientific officer, Royal Botanic Garden, Edinburgh; Dr. Enid Charles, reader in demo. graphy and vital statistics, University of Birmingham; Dr. E. F. Collingwood, Lilburn Tower, Northumberland; Dr. I. MacP. Dawson, senior lecturer in electron microscopy, University of Glasgow; Dr. J. Duckworth, Rowett Research Institute, Bucksburn; Mr. W. G. Emmett, reader in experimentel education, University of Edinburgh ; Dr. C. E. Foister, chief plant pathologist, Department of Agriculture for Scotland; Mr. H. D. Griffith, lecturer in natural philosophy (medical physics), University of Aberdeen; Prof. G. Hibberd, Dixon professor of mining, University of Glasgow; Prof. N. Kemmer, Tait professor of natural philosophy, University of Edinburgh; Mr. T. Lawrie, general manager, North of Scotland Hydro-Electric Board; Prof. R. D. Lockhart, professor of anatomy, University of Aberdeen; Dr. C. Long, senior lecturer, Department of Biological Chemistry, University of Aberdeen ; Dr. D. K. C. MacDonald, director, Cryogenic Laboratory, Division of Physics, National Research Council, Canada; Miss Agnes E. Miller, lecturer in zoology, University of Glasgow ; Prof. D. C. Pack, professor of mathematics, Royal Technical College, Glasgow; Dr. Mary Pickford, reader in physiology, University of Edinburgh ; Dr. B. Raistrick, research manager, Scottish Agricultural Industries, Ltd. ; Prof. G. S. Rushbrooke, professor of theoretical physics, King's College (University of Durham), Newcastle upon Tyne; Mr. G. I. Scott, consultant ophthalmologist, Edinburgh; Dr. N. B. Slater, lecturer in applied mathematics, University of Leeds; Dr. R. B. Strathdee, reader in chemistry, University of Aberdeen; Mr. J. Wallace, head of the Science Department, Melville College, Edinburgh.

\section{Research into Rain-making}

RePLyING in an adjournment debate in the House of Commons on February 23 to Mr. G. de Freitas's request for increased research into weather modification, the Under-Secretary of State for Air said that the Meteorological Office is studying reports of rain-making activities all over the world; but he was advised that available scientific evidence on the practical side is not entirely convincing. Since the Advisory Council on Scientific Policy expressed the opinion in 1951 that no expenditure of effort on large-scale field trials was called for without further research, the Meteorological Office has carried out research on cloud rainfall problems, and practical experiments have been made by the Meteorological Research Flight of the Royal Air Force, more with the object of increasing knowledge than of trying to produce rain. Rain-making, and the present state of our knowledge of the subject, will shortly come before the Physical Sub-Committee of the Meteorological Research Committee, which advises the Secretary of State for Air on this subject, and the future course of action will then be reconsidered.

\section{National Institute of Sciences of India : Council} and New Fellows

THE Council of the National Institute of Sciences of India has been elected for 1954 as follows: President, Sir K. S. Krishnan; Vice-Presidents, Prof. S. K. Banerji and Dr. B. Mukerji ; Treasurer, Prof. D. S. Kothari ; Foreign Secretary, Prof. P. C. Mahalanobis ; Secretaries, Prof. R. C. Majumdar and Dr. B. P. Pal ; Editor of Publications, Prof. J. M. Sen ; Members of Council, Prof. S. P. Agharkar, Prof. K. N. Bagchi, Dr. J. L. Bhaduri, Dr. Verrier Elwin, Prof. P. S. Gill, Prof. A. C. Joshi, Dr. V. R. Khanolkar, Dr. M. S. Krishnan, Dr. D. R. Malhotra, Prof. S. K. Mitra, Dr. M. A. Moghe, Dr. H. S. Pruthi, Prof. B. Sanjiva Rao, Dr. V. Subrahmanyan, Prof. N. R. Tawde, Mr. M. S. Thacker and Dr. A. C. Ukil ; Representative of the Government of India, Dr. D. N. Wadia; Representatives of the Asiatic Society, Prof. H. K. Mookerjee and Dr. U. P. Basu ; Representatives of the National Academy of Sciences, Prof. Shri Ranjan and Dr. R. K. Saksena; Representatives of the Indian Science Congress Association, Dr. S. L. Hora and Dr. B. N. Prasad; Ex-Officio Members (Past Presidents), Dr. Baini Prashad, Dr. J. C. Ghosh, Dr. D. N. Wadia, Sir S. S. Bhatnagar, Prof. S. N. Bose and Dr. S. L. Hora.

The following elections have also been made to fellowships of the Institute. Honorary Fellows : Prof. Sydney Chapman, recently Sedleian professor of natural philosophy, University of Oxford; Prof. V. A. Engelhardt, Soviet Academy of Sciences, Moscow; Prof. W. Heisenberg, director of the Max Planck Institute, Göttingen; and Prof. Paul Karrer, director of the Chemistry Institute, University of Zurich. Ordinary Fellows : Dr. B. C. Basu, research officer in entomology, Indian Veterinary Research Institute, Izatnagar; Dr. S. K. Bhattacharya, assistant professor of chemistry, Institute of Technology, Kharagpur; Prof. K. Chandrasekharan, professor of mathematics, Tata Institute of Fundamental Research, Bombay; Prof. K. R. Dixit, professor of physics, Institute of Science, Bombay ; Dr. S. Ghosh, professor of chemistry, University of Allahabad; Dr. A. G. Jhingran, superintending geologist, Geological Survey of India, Calcutta ; Prof. S. Kilpady professor of geology, University of Nagpur; Dr. Z. R. Kothavala, director, Dairy Research, Government of India, Bangalore; Dr. L. S. S. Kumar, principal, College of Agriculture, Poona ; Dr. N. V. Modak, special engineer, Bombay Municipality ; Prof. C. Radhakrishna Rao, professor, Indian Statistical Institute, Calcutta; Mr. A. K. Roy, officiating deputy director-general of observatories, Meteorological Office, New Delhi ; Dr. R. N. Sen, lecturer in mathematics, University of Calcutta; 